\title{
'Climatizing' military strategy? A case study of the Indian armed forces
}

\section{Dhanasree Jayaram ${ }^{1}$ (D)}

Published online: 30 May 2020

(C) The Author(s) 2020

\begin{abstract}
Climate change is increasingly shaping security narratives, including military strategy. While considering climate change a security issue, the military's role in this discourse and praxis becomes critical as a security actor. However, the interrelationships between climate change, security and the military are conceived and approached by different states diversely. Within different states, this triangular relationship is guided by processes with varied practical/policy implications. While 'securitization' has generally been used to explain climate security, other processes such as 'climatization' have assumed significance, wherein security practices are climatized. The Indian military too has been engaging with security implications of climate change, but by using approaches distinct from Western states, which have been the usual focus in such analyses. In this paper, the framework of climatization is used to analyse the triangular relationship, using the case study of the Indian military-by categorizing climatizing moves as symbolic, strategic, precautionary and transformative.
\end{abstract}

Keywords Climatization $\cdot$ Securitization $\cdot$ Riskification $\cdot$ Indian military $\cdot$ Climate security

\section{Introduction}

Climate change is increasingly being recognized as an international security challenge that impinges on a nation state's military tactically, operationally and strategically. The involvement of militaries in environmental and climate security has been further bolstered through initiatives such as the International Military Council for Climate and Security (IMCCS), which was launched at the 2019 Planetary Security Conference in The Hague. The role of the military in environmental and climate

Dhanasree Jayaram

dhanasree.j@manipal.edu; dhanasreej@gmail.com

1 Department of Geopolitics and International Relations \& Centre for Climate Studies, Manipal Academy of Higher Education, Manipal, Karnataka, India 
tasks is facilitated through various frames and lenses. While 'greening defence' is a more popular rhetoric (particularly against the background of the military being one of the biggest polluters), framing of climate change as a 'threat multiplier', exacerbating security threats/risks, especially in conflict scenarios, is also gaining traction. Why militaries care or need to care about climate change has been enunciated by making a case for potential large-scale deployment of militaries for Humanitarian Assistance and Disaster Relief (HADR), humanitarian intervention in conflict-ridden areas and even the impacts of climate change on military assets and installations. Furthermore, the military, being self-sufficient and multifaceted, is viewed as an agency that could lead environmental stewardship in its own domain as well as in coordination with civil actors in other domains, thereby becoming a part of the solution.

However, the military-climate security interface is neither straightforwardly explained nor diversely represented. As the relationship between climate change and security itself is conceived and approached diversely by different states, the practical implications of involving the military in climate change-related issues are being debated in many contexts. Fears related to 'militarization' of climate change and 'green washing' in this context have not been adequately addressed. Most of the debates/discussions on this theme are driven by institutions and experts based in the Organisation for Economic Co-operation and Development (OECD) ${ }^{1}$ countries. Among the countries in the developing world, while some (especially the most vulnerable ones) are proactive in pushing the climate security discourse, others are also moving towards recognizing climate change as a critical security challenge that militaries have to deal with, but to a much lesser degree. India's Joint Doctrine of the Indian Armed Forces (Headquarters 2017) released in 2017 is a case in point, but the military's role in dealing with climate security challenges is not yet operationalized in any codified form. India's case assumes further significance in the light of the differing positions; based on its developmental concerns, it has adopted in the United Nations Security Council (UNSC) discussions on climate security.

The creation of epistemic networks such as the IMCCC could be considered an act of enhancing the legitimacy of military actors through their representation as agents of climate action, directed at achievement and maintenance of security, peace and stability. Herein, the framing of climate change as a security threat or a 'threat multiplier' assumes significance, thereby attempting to raise the urgency of the issue and placing the military as a central actor in global climate governance through securitization of climate change. Another angle that is more prominent in developing countries such as India is the gradual movement towards mainstreaming climate change into military strategy based on the military's perceptions of climate vulnerabilities as well as historically established concordance between civil and military actors on their respective roles. This can be termed as 'climatization'. Whether it is impacts of climate change on the military or the military's contribution to the national climate goals, climatizing moves are on the rise. For instance, the melting of Siachen glacier is reportedly forcing

\footnotetext{
1 The web link to Organisation for Economic Co-operation and Development (OECD) is: https://www. oecd.org/.
} 
the Indian military to change its strategy in the region. While 'greening' efforts have been underway for decades, there is now greater focus on integration of climate concerns into military strategy. Climatization is also being driven by increasing involvement of the Indian military in HADR, 'in aid to civil authorities'. Nevertheless, the 'threat multiplier' narratives are largely restricted to the academic and grey literature, that too in a narrow sense, with a larger focus on nonmilitary measures.

In this context, this paper analyses the Indian military's engagement with climate issues - as a part of its security practices - using the framework of 'climatization'. It enunciates the drivers, processes and characteristics of 'climatization' of military strategy within the Indian armed forces. In this study, climatization is classified into four broad types (as 'climatizing' moves akin to securitizing moves), based on the motivations of the actor and nature cum intensity of the process: symbolic (including soft climatization and/or greenwashing), strategic (climate bandwagoning for acquiring funds), precautionary (climate mainstreaming for preparation) and transformative (deep climatization in the form of engagement with mitigation and adaptation-related actions). Since the existing literature mostly looks at securitization (or lack thereof) of climate change in the Indian context, this paper goes one step ahead to identify other processes, mainly climatization, that have manifested themselves in different ways within the Indian military, due to either organizational dependencies (in cooperation with civilian agencies) or autonomously developed procedures. The paper argues that the Indian military's engagement with climate change-related issues is best analysed through the framework of climatization, based on the four categories identified above. It also asserts that climatization is still nascent in the Indian context, thereby giving room for further exploration of the reasons for the gradual pace of integration of climate change into military strategy.

The paper draws mainly on official documents and interviews conducted by the researcher with military, policy and academic communities. It adopts a qualitative, interpretative, fundamental (linking theory to empirics) and inductive approach, and case study research design (India in this case) to develop research on climate security and the military from the point of view of climatization. In addition, it refers to academic and grey literature on securitization, climate security, riskification, climatization and climate security-military interface (in general). The study attempts to develop an analytical framework of climatization, based on the limited existing literature on it (as compared to securitization), divergences with the notions/processes of riskification and securitization and, more importantly, empirics of the actions of the Indian armed forces related to climate change-related issues. The paper, will therefore, help develop the discourse on climatization further, if not as an alternative and/or in parallel to the discourse on securitization, but in tandem with securitization and riskification.

\section{From securitization and riskification of climate change to climatization in the military domain}

The military's role in the climate change discourse can arguably be operationalized only through the securitization process, considering that the military is essentially a security actor (that too mostly expressed in traditional terms). However, there are 
other processes such as 'riskification' (hinging on securitization) and 'climatization' (upturning securitization) that could also help analyse the military-climate change interface. These approaches emerged in the post-Cold War context, wherein traditional notions of security began to be challenged and rediscovered. Securitization theory (Copenhagen School) attempts to blend realist/neorealist notions of security based on 'survival in the face of existential threats' with a focus on widening the scope of security to go beyond state or military security.

Securitization theory has been criticized on several fronts, mostly in relation to its focus on exceptionalism - that supposedly involves breaking of 'normal political rules of the game' (such as democratic processes), and adoption of a logic of exclusion and urgency along with emergency/extraordinary measures (Buzan et al. 1998). The idea of security as a 'speech act' (based on social construction), according to the Copenhagen School, has also been criticized. For instance, the Paris School uses governmentality, as an approach to securitization, to explain how the state uses its bureaucratic institutions, agencies, instruments, programmes and techniques to implement a set of measures that later transform into norms. It moves away from the exceptionalism of the Copenhagen School and concentrates on 'everyday routine and technocratic practices' (Balzacq et al. 2010). Furthermore, Bilgin (2010) and Wilkinson (2007) challenge securitization theory's Eurocentricism in their works by questioning its application in non-West contexts.

Securitization theory has influenced the construction of environment as a security issue. On this front, the debates on whether to securitize or not to securitize, how to securitize and what constitutes a successful and/or positive securitization have occupied a prominent position in security studies (Dyer 2001; Floyd 2008; Trombetta 2011). Furthermore, critical security theorists use the concept of 'emancipation' (in construction of security) - 'freedom from unacknowledged constraints, relations of domination, and conditions of distorted communication and understanding that deny humans the capacity to make their future through full will and consciousness'-in building linkages between security and environmental change (McDonald 2012).

When it comes to securitization of climate change from a military perspective, a section of the existing literature (mostly grey) places it in the context of environmental conflict, and hence loaded with traditional notions of military security (Campbell et al. 2007; Shwartz and Randall 2003; Smith and Vivekananda 2007). HomerDixon (1994), (2007) of the Toronto Group, famous for his works on intrastate conflict as a result of interaction between renewable resource scarcity and socio-economic dynamics, highlights the pressure that climate change could put on the military forces by creating unconventional challenges such as insurgencies. Floyd (2010) warns that climate security, as propounded by experts (with close ties with the military) in the USA, caters to the 'national security' discourse and 'military readiness', giving a 'shield' to those policy-makers who are opposed to adoption of greenhouse gas (GHG) emissions reduction targets. In other studies, the 'greening' activities of defence (to reduce ecological footprint) are seen as a means of legitimizing military spending (Chaturvedi and Doyle 2015).

Securitization of environmental and climate change is often correlated and/or conflated with militarization. While Barnett (2001) calls militarization the 'single biggest institutional risk to human beings', Dalby (1992) argues that this provides 
the licence to the armed forces to unleash further environmental damage by securing the status of 'protected polluters'. Deudney (1991) goes a step ahead to assert that military organizations, being highly 'secretive', 'hierarchical' and 'centralized', are not suited to environmental protection since they are 'far removed from the experience of the civil society.' Similarly, Gilbert (2012) asserts that since the military takes a very narrow view of security, typically the traditionalist view'based on nationalistic, defensive, territorial lines, viewed in statist terms' and 'a model of external threats, based on the idea of resource conflict'-involving the military in activities such as HADR leads to military 'encroachment' on the civilian role. Gilbert (2012) is also opposed to the idea of 'othering' the climate, a process that casts climate change as an enemy. Hence, the drivers of securitization, in these scholars' opinion, are mainly sustenance of military budget and perhaps, the existence of the military itself, owing to the apprehension about downsizing of the military in many countries in the post-Cold War era.

Riskification is another concept that is often used in the context of climate change. Although it primarily challenges the notions of securitization of climate change (in terms of the referent object, nature of the threat, and proposed response), it also tends to embrace a similar logic and acts as a securitization multiplier. Riskification can be referred to as the framing of climate change as a risk (rather than a threat) through 'a social process of constructing something politically in terms of risks', with a focus on 'conditions of possibility of harm'. It renders governance, preparation, anticipation, precaution, prevention and similar other tools more relevant than the securitization's preoccupation with defence, deterrence and fight/war against an external enemy. In this context, environmental logic of 'precautionary principle' and security logic of 'anticipatory defence' become two sides of risk policy (Corry 2012). Criticizing the logic of climate security linkages, built through the prisms of violent conflict triggered by resource stress/scarcity and/or inclusion/legitimization of military measures in nonmilitary sectors, the risk framing of climate change has been given preference in some literature (Trombetta 2008). However, a risk-based approach to securitization is also known to 'alter procedures' and 'play down other options' (with reference to changes in military sector), thus leading to 'less extreme but permanent and infinitive state of emergency' (Lucke et al. 2014).

Riskification or the risk logic is prominently used in many studies to establish the military-climate interface. For instance, Dabelko (2009) has provided the basis on which security communities like the military, with their 'habit of planning for all contingencies' are inclined to analyse 'a wide range of climate change's impacts through a security lens that includes, but extends far beyond, potential contributions to conflict'. Questioning the dependence of climate policy on palaeo-records and absolute certainty (about scientific evidence), Briggs (2012) uses the risk logic, without referring to it directly. He argues that the military, by default, practises 'contingency planning' and adopts the 'precautionary principle', and therefore, it is natural for it 'to reduce surprise when possible' and 'to prepare appropriate responses when novel conditions are encountered'. In this way, a broader view of security comes into effect, which would help tackle greater uncertainty and hence, greater risk. 
In this case, the discourse moves away from the securitization approach, and even though, at the outset, the riskification approach seems to be the guiding process, there is also an inherent element of climatization, which manifests itself in the form of climate mainstreaming - integrating principles of environmental and climate risk assessment into military planning, operations and strategy. On the one hand, the military is presented as an agent of climate risk governance by providing tools and approaches to govern and manage risks associated with climate change that emerge often as 'triggering mechanisms for slow-onset threats and pressures'. On the other hand, the climate logic also comes into play in the opinion that climate change should not be regarded primarily as a military concern, but climate change concerns need to be addressed by the military in its own domain and through civil-military coordination (Briggs 2012).

Climatization, which forms the crux of this paper, is analysed and utilized in terms of how climate change has begun to dominate other domains of global and local politics and governance, and how the climate logic introduces new principles of action and practices in the security sector (Aykut et al. 2017). Climatization can be defined as - 'existing security practices are applied to the issue of climate change and that new practices from the field of climate policy are introduced into the security field' (Oels 2012). According to Oels (2012), the defence sector is already on the path of climatization through a gradual process of restructuring. This is more evidenced by its greater involvement in Humanitarian Assistance and Disaster Relief (HADR) and similar operations - whether it is as 'Responsibility to Protect' or as a civil-military intervention in 'climate change hot spots', characterized by 'weak or failing states'. However, this line of thinking is 'exceptional' as it does not apply to all the countries that acknowledge climate change as a security issue within their national security thinking, policies or strategies.

'Environmentalization' is yet another thought process (closely associated with climatization) that has been used in the context of peacekeeping forces through integration of environmental norms/concerns into UN peacekeeping missions/operations/practices (for example, reducing the environmental/ecological impacts of the peacekeeping operations). Environmentalization in this context leads to not only framing of peacekeeping as a part of the 'environmental realm', but also 'securitization of the environment' (Maertens 2019). In any case, the advocates of both riskification and climatization argue that the logic adopted in linking climate change with security is not only that of security/securitization, and moreover, attempts to 'securitize' climate change have not resulted in 'extraordinary measures' being adopted internationally (Oels 2012; Corry 2012).

In another related argument, the logic of 'greening security' is also used to analyse the 'positive transformative role' of the military, 'given the enormous resource base of military establishments and continuing public investment in militaries worldwide' in the realm of environmental peacebuilding (Ali and Pincus 2018). This logic, on the one hand, challenges the climate-conflict nexus, and on the other hand, it attempts to reinvent the military's function as an instrument of peacebuilding through environmental means, which is closely related to environmentalization and climatization. Whether or not environmental and natural resources can serve as a source of cooperation, trust and confidence building, this logic is gaining momentum 
even more with the UN's (particularly the UN Environment Programme) contributions to the existing literature (Conca and Wallace 2009).

\section{Military-led discourses on climate change and security}

Despite criticisms, there has been a huge swell in the amount of grey literature linking climate change to security from a military perspective, especially since the release of the report, titled, 'National Security and the Threat of Climate Change', by the Center for Naval Analyses (CNA), in 2007. This report, collated by 11 retired military officers, is an exemplary case of the military acting as securitizing actors. It labels climate change a 'threat multiplier' and states that the US military would be forced to intervene in many parts of the world, 'either alone or with allies, to help provide stability before conditions worsen and are exploited by extremists.' It might also be expected to 'undertake stability and reconstruction efforts once a conflict has begun, to avert further disaster and reconstitute a stable environment.' While this discourse related to climate security - framing climate change as a threat-continues to remain a dominant one in the military circles, there are other military experts who use the frame of 'greening defence'.

'Greening defence' caters to the inversion of military's image as one of the biggest polluters or destroyers of the environment. It also exemplifies advocacy of the use of military resources for the purpose of environmental protection and climate action. In essence, this frame largely invokes the grammar of climatization, whereby military activities and assets are climatized in a 'symbolic' manner. At the same time, the 'whole-of-government approach' (based on 'diplomacy', 'development' and 'defence'), advocated primarily by sections of the US military and reflected in the official documents released by US government agencies (including Quadrennial Defence Reviews), is influenced by framing of climate change as a 'threat' to military and national security (Hartman et al. 2012) (Parsons 2011). This approach is presupposed on two factors - the expanding role of the military in climate change adaptation and HADR and the military being the 'best resourced of all federal agencies' (Butts 1999). It is therefore reflective of 'strategic' climatization in the form of climate change bandwagoning, by which institutional linkages are developed to incorporate military and security actors in climate change governance.

The frame of 'greening defence' has been used by multiple international organizations, including the UN and North Atlantic Treaty Organisation (NATO). Some studies view it as 'greenwashing' (or 'symbolic climatizing move) in the light of cooption of the 'language and imagery of environmentalism' that could 'assuage the concerns of an environmentally conscious public without having to actually clean up unsound practices', which is to shift attention from the environmentally destructive activities of the military (Harris 2015). However, it could also be viewed as weak or soft environmentalization and climatization as seen in the case of the NATO Green Defence Framework (North Atlantic Treaty Organisation 2014). Under this initiative, 'green security challenges' are linked to 'green solutions' (targeted at environmental protection and energy efficiency) to advance the purposes of 'limiting detrimental impact, saving money, and optimizing operational effectiveness'. This 
follows a risk-based approach and pathway of 'climate mainstreaming', by which incremental reforms are adopted within the military to facilitate military effectiveness as 'precautionary' moves.

The focus on the military's role in climate security has been further amplified by the formation of epistemic networks such as the Global Military Advisory Council on Climate Change ${ }^{2}$ (GMACCC) in 2009 and the IMCCS in 2019, consisting mainly of serving and retired military personnel (in addition to think tanks). These networks also, in a way, perpetuate the security and risk logic based on a discursive approach, by presenting a case for discussing climate change through the security/ risk lens. Strategically, they mostly emphasize the need for the security communities to prepare for the risks of climate change and use this as a tool to advance climate action and their own role in climate change governance (including in the UNSC). The IMCCS, for example, focuses on 'global and regional risk assessment', scenarioizing/games, gauging risk perceptions and so on, which fit into the category of 'precautionary' climatizing moves. At the same time, this has, in fact, given rise to alternative formulae such as 'responsibility to prepare'-instead of the commonly used 'responsibility to protect'-thereby incorporating security concerns associated with climate change in the national security assessments and strategies (Werrell et al. 2017). It must be, however, noted here that securitization and/or riskification in this context can be correlated with the climatization of security actors as it also complements 'precautionary' climatizing moves that could then act as securitization multipliers.

\section{Perspectives on security and climate change in India}

India is among the countries that have called for caution when it comes to 'securitization' of climate change, especially introduction of this topic in the UNSC (since 2007). It has maintained that 'a security approach to a critical challenge facing humanity may in fact hinder the global collective effort' and that 'thinking in security terms usually engenders overly militarized solutions to problems, which inherently require nonmilitary responses to resolve,' thus bringing the wrong actors to the table' (as observed by India's permanent representative at the UN in 2019). When the issue was brought up in the UNSC in 2019, India's representative asserted that while securitizing climate change could raise public awareness about climate change and perhaps lead to investment of greater amount of resources in tackling it, it could also pit countries in a competition when the most productive approach is cooperation' (United Nations 2019). Yet, the 'lexicon of security' is employed by state and non-state actors in India in order to highlight the impact of climate change on other entities that are expressed in security terms, policy-wise, such as food security, water security and energy security. The logic used in this case is different from the predominant security logic though. Instead of conflicts, disasters, instabilities

\footnotetext{
${ }^{2}$ More information regarding the Global Military Advisory Council on Climate Change can be found at: http://gmaccc.org/.
} 
and other similar utterances, this logic is built upon developmental concerns, such as livelihoods, hunger, energy shortage, public health, poverty and water scarcity (Ramesh 2015).

Based on several indicators such as references to the 2008 National Action Plan on Climate Change (NAPCC), government-sponsored Indian Network for Climate Change Assessment report, and statements made by several members of the administration, including that of Prime Minister's Council on Climate Change (PMCCC), Sahu (2017) concludes that climate change is securitized in the Indian context. They invoke both 'urgency' and 'complexity' in order to stress the 'existential' nature of the 'threat'. Barthwal-Datta (2012) uses the cases of 'scientific policy communities' to explore the role of non-state actors in securitizing climate change in India. Their proximity to the state actors and their visibly influential role in drafting the NAPCC - owing to their 'social capital' and 'expert authority'-further enunciates their function as 'securitizing actors'. The success of the securitizing move in this case is seen through the lens of its acceptance by the 'target audience'. One of the cases that is often used to highlight security implications of climate change for India is that of 'climate migration' or 'climate change refugees' from Bangladesh (Chowdhury 2009). This discourse is further accentuated by the narratives on India fencing the boundary with Bangladesh to stem the flow of illegal immigrants into its territory (Ranjan 2016), which Chaturvedi and Doyle (2015) consider 'underlying geopolitics of fear and boundary-reinforcing cartographic anxieties about climate change-induced displacements and migrations'.

However, the above-mentioned arguments can be countered on the basis that the practice of securitization can be considered successful only when the securitizing move leads to change in behaviour by the concerned agent or, in other words, adoption of certain policies by the government (Floyd 2011). At the same time, internationally, India has opposed the alarmist discourse on climate change-security nexus (such as climate migration), primarily guided by the postcolonial context in which the Western notions of climate security are seen as 'arrogant' and signs of 'interference'. In contrast, India invokes the human security aspects of climate security, including rural and urban development, or energy security that takes account of climate change concerns (Boas 2014). In short, it can be surmised that India has treated climate change as a security concern at the domestic level (in addition to its other framings), but only as a developmental concern at the international level.

\section{The discourse on climate change and the Indian military}

The literature concerning the role of the Indian military in the intersection between climate change and security mostly is contributed and propagated by ex and serving military officials, members of the administration (concerning national security, foreign policy and/or environmental policy) and occasionally by researchers based in think tanks (defence and strategic studies). On the one hand, this literature adopts both security and risk logic to reinforce the security implications of climate change for military security and, more broadly, national security. On the other hand, it also delineates elements of climatization that have been overlooked so far. Dasgupta 
(2016), former PMCCC member and climate change negotiator, analyses threats posed by climate change to the Indian military as physical impacts on defence installations and infrastructure, and disaster management (including scaling up of efforts by the armed forces). Pai (2017), co-founder and director of an independent think tank in India, identifies glacial recession (in the Himalayas), rising sea levels (in the Indian Ocean Region), extreme weather events and changing river courses (shared by India and its neighbours) as major threat multipliers that could 'potentially' trigger civil wars, military invasion, migration and other similar scenarios. These scenarios could significantly alter the security environment of South Asia, in which the Indian armed forces operate, and therefore, he recommends that they develop science, intelligence and equipment/operational capabilities to be able to prepare effectively for various conflict scenarios in which climate-related variables are intrinsic, as well as address climate risks in general. In essence, both these perspectives add to the climatization narratives that draw upon precautionary moves.

Singh (2015), a former naval officer, uses a combination of security and risk logic to amplify the threats posed by climate-induced displacement and migration in the Indian Ocean Region. However, in this case too, a case for precautionary climatization is made, aimed at climate mainstreaming, as reflected in the actor motivations. He also throws light on the potential for maritime disputes in the region, especially due to conflicts over 'Exclusive Economic Zones (EEZs) and seabed resources' owing to the threat posed by rising sea levels to low-lying islands. Besides, he describes the implications of climate change for maritime operations- 'navigation and pilotage to operational exercises, and maintenance of ships, engines and other equipment.'

Besides conflict scenarios, some works use the lexicon of climatization to reflect upon the impacts of environmental and climate change on the functioning and operability of the Indian military, and how it could adapt to the changing environment as well as reduce its environmental footprint. Kumar (2012), a serving air force officer, proposes that the Indian armed forces engage in adaptation and mitigation strategies such as resource management, phase-out of ozone-depleting substances (ODS), energy efficiency and conservation, waste management and environmental training. A case for military environmental leadership using four key drivers-'economic sense', 'operational spin-offs', 'safe environment' and 'socially responsible behaviour' - can be interpreted as both transformative and strategic.

\section{Climatization of military strategy in India: a practical viewpoint}

The Indian military is known to supplement a nation state's foreign policy and national security objectives by helping build 'bridges of friendship and strengthen international cooperation' in addition to deterring war or intervention by the adversaries, thus helping shape a favourable maritime environment for the promotion of national interests (Indian Navy). The military's function of engaging in 'Military Operations Other Than War' (MOOTW) and exercising soft power in the form of HADR diplomacy is being streamlined further through the climate logic. HADR is projected as an instrument to 'shape local political contexts', and since it operates in 
a non-quid pro quo and/or nonzero sum game setting, the expectation is that countries would automatically grow closer to each other, and this in turn would help major powers like the USA to maintain its presence globally (Capie 2015). These are indicators of climatization as climate change increasingly becomes an intrinsic part of military planning and strategy, not just nationally but also regionally and internationally.

Unlike in some of the Western contexts, where climate change features as a prominent national and international security concern (for example, in the national security strategies), in India, this is not the case. In the absence of a codified national security doctrine or strategy, India's national security goals are usually identified and pursued by the National Security Council Secretariat (NSCS) in Prime Minister's Office (PMO), also assisted by the National Security Advisory Board (NSAB), which has been contributing to studies and analyses on India's national security (including the annual national security reviews). In the policy context, climate change is yet to find a constant position in the national security matrix due to various reasons, including the lack of scholarship on the linkages between climate change and security, as pointed out by Sameer Patil (2014, personal communication), a former member of NSCS. As a result, one could argue that the joint military strategy that derives from the national security policy and strategy also does not prioritize climate change. However, Jasjit Singh (2011, personal communication), a retired air force officer and former director of two defence think tanks based in New Delhi, asserts that the country's national security interests are primarily enshrined in the country's Constitution. He chooses to define national security as the preservation of the core values of a nation that are prescribed in the Preamble, that is, justice, liberty, equality and fraternity. It also entails the protection and promotion of the vital national interests, which include elements of environmental governance. As a corollary, the Indian military has a duty to protect these values.

Climatization of military strategy is happening at multiple levels in varying degrees across the three services of the Indian armed forces. The Indian military is following the process of 'climatization', mostly in tune with the local contexts, requirements and demands, but also partly borrowing ideas from the Western discourse on climate security. Climate change has found a place in the Joint Doctrine of the Indian Armed Forces (JDIAF), released in 2017. It lists climate change as a "nontraditional security' issue, akin to its categorization by state and non-state actors in general in India, and states that fallouts of climate and environmental change such as migration and civil strife at times require security responses, including from the military. However, the primary focus is on HADR and to ensure that the 'readiness of the Armed Forces performing such missions' is 'optimum at all times'. Interestingly, it refers to defence diplomacy as a priority area, by which India's soft power could be promoted and the nation's 'reputation as a responsible power' could be enhanced. These efforts can be classified as both symbolic and precautionary climatizing moves, with both preparedness and national image projection at the centre of actor motivations.

In fact, HADR has been an indispensable part of India's joint military strategy for a long time, as a part of its mandate of 'in aid to civil authorities'. The 2004 Indian Ocean Tsunami led to the introduction of policy guidance document on 'Armed 
Forces Assistance for National Disasters' by India's Defence Crisis Management Group (DCMG) that tasked 'the Integrated Defence Staff (IDS) to coordinate the relief effort with the Ministry of Defence [MoD], Ministry of Home Affairs [MHA], the Ministry of External Affairs [MEA] and other relevant departments and agencies' (Mukherjee et al. 2012). ${ }^{3}$ Similarly, the National Policy on Disaster Management 2009 acknowledges that the 'Armed Forces are called upon to assist the civil administration only when the situation is beyond their [the latter's] coping capability'. It also reaffirms that 'on account of their vast potential to meet any adverse challenge, speed of operational response and the resources and capabilities at their disposal, the Armed Forces have historically played a major role in emergency support functions' (National Disaster Management Authority 2009).

In effect, the principle of 'in aid to civil authorities' forms a bedrock of the military's engagement with climate change-related issues. This applies to not only HADR, but also other activities such as afforestation/land restoration, as in the case of the Ecological Task Force (ETF), world's reportedly first ecological unit of the Territorial Army, raised in 1982. The first battalion was deployed in Uttarakhand (in the Shivalik Ranges of the Himalayas) to afforest severely degraded land (caused by indiscriminate and illegal limestone mining in the region) and eight more battalions (besides a battalion for cleaning the Ganges, the longest river within India) have been raised in various parts of the country since then (Territorial Army). The rationale behind raising the ETF has been that the civilian agencies such as the forest departments as well as non-state actors (non-governmental organizations) could not achieve what the ETFs could in limited time. These units could 'execute specific ecology-related projects with a military-like work culture and commitment' (Territorial Army). Since the military is known to operate in inhospitable, remote and ecologically vulnerable terrain as well as extreme weather conditions more than the civilian agencies, it is considered an asset in the country's environmental preservation agenda, especially in settings, where the civilian agencies can either not cope or need military assistance.

In HADR too, this logic comes into effect, which in turn enhances the role of the military in it. Their ability to provide relief supplies to inaccessible and vulnerable areas that are affected most by disasters is incomparable with the civilian agencies. The National Disaster Response Force (NDRF)_'a specialized disaster response force', consisting mainly of paramilitary personnel-was formed in 2006 under the MHA, ${ }^{4}$ but it is constrained by many factors. Its presence in terms of strength and location is limited, which hampers their mobility, unlike the armed forces that are much bigger in numbers. The military's presence is nationwide and they are equipped with airlift capabilities that put them in a better position to tackle major disasters than the NDRF, which is dependent on the military for airlift and

\footnotetext{
3 The role of the IDS is primarily to build "synergy and consensus through intra-service deliberations and ensuring optimisation of resources through rightful prioritisation for procurements, joint doctrines, joint training and common procedures." More information can be found in the press release of MoD: http://pib.nic.in/newsite/PrintRelease.aspx?relid=105931.

4 More information about the National Disaster Response Force can be found here: http://www.ndrf.gov. in/about-us.
} 
is present only in 12 locations in the country (2014, personal communication with NDRF officials).

Increasingly, the argument that the Indian armed forces should contribute to nationwide efforts at climate change mitigation and adaptation is also strengthening with 'climate mainstreaming' gaining momentum in the armed forces. It stems from the point that India's Nationally Determined Contributions (NDCs) are ambitious and unless all the sectors of the country, including the military contribute, the goals would be difficult to achieve. Therefore, the military has, for instance, started to contribute to enhancement of renewable energy generation capacity by diverting defence lands to solar parks. The MoD has declared that $300 \mathrm{MW}$ of solar projects (rooftop and utility-scale power projects) would be set up in different parts of the country by defence establishment, especially on vacant lands that are not being used by the three services, with indigenously manufactured modules and equipment (Mittal 2015). The ETFs could be a potential partner in the National Mission for a Green India (under the NAPCC), especially since the Indian Government has set a goal of creating 'an additional carbon sink of 2.5 to 3 billion tonnes of carbon dioxide equivalent through additional forest and tree cover by 2030 ' in its NDCs. ${ }^{5}$ These moves are more transformative in nature than precautionary, as it goes beyond the military's primary responsibility.

Similarly, the Chief of the Naval Staff, while participating in the Indian Government's flagship, Swachh Bharat Abhiyan (Clean India Campaign) Awareness programme, in 2014, asserted: 'The naval community will aim to lead by example and continue to contribute in significant measure, to the nation's efforts, for a clean and green future' (Press Information Bureau 2014a). As a result, a Green Cell has been established at the Navy Headquarters (in 2016) that is tasked to coordinate and monitor implementation of the 'green initiatives' by all segments of the navy. Besides announcing its intent to convert India's largest naval base in Karwar (on the western coast in Karnataka) as a 'smart green naval base', it plans to 'incorporate concepts of energy efficiency from the ab initio stages' (in augmentation and acquisition of assets or infrastructure projects) and achieve 'zero carbon footprint' (Press Information Bureau 2014b). The navy has expressed its desire to support the Indian Government's $100 \mathrm{GW}$ solar energy target by 2022 by having its own target of a $21 \mathrm{MW}$ solar installation, dedicating 1.5 per cent of its works budget to renewable energy generation as well as deploying rooftop solar panels. It is also reportedly working towards developing warships that run on biofuels (Pubby 2016) and harnessing ocean thermal energy and wave energy after doing a comprehensive feasibility study with the help of civilian authorities like the Ministry of New and Renewable Energy (MNRE) (Press Information Bureau 2016).

Climatization, through incremental reforms at various levels of the military, is pushing it towards an institutionalized approach that can ensure 'co-benefits' (in this case, cost-cutting, adaptation of equipment, infrastructure and activities, safety and improvement of image/reputation). Among the co-benefits, 'winning the hearts and

\footnotetext{
5 India's INDCs can be found at: https://www4.unfccc.int/sites/submissions/INDC/Published\%20Doc uments/India/1/INDIA\%20INDC\%20TO\%20UNFCCC.pdf.
} 
minds' (apart from maintaining operational effectiveness) through a form of symbolic climatizing/environmentalizing move is also happening, particularly in regions that are conflict-ridden. For instance, Defence Institute of High Altitude Research (DIHAR) of Defence Research and Development Organisation (DRDO) has established solar-based green houses in Ladakh, which is stricken by terrorism and interstate conflict, to ensure supply of fresh food to the soldiers in the harsh environment (cold desert). ${ }^{6}$ Regular movement of vehicles to transport supplies has adverse impacts on the glaciers of the region. In addition to GHG emissions reduction, it also led to propagation of the practice of organic farming along with decentralization of food production and economy, in the larger interest of the public in the region (information gathered through personal communication with officials of Bombay Natural History Society) in 2014.

The growing literature on the potential impacts of climate change on the military, wherein risks, uncertainty and urgency associated with climate change are highlighted, reflects upon the necessity of enacting precautionary climatizing moves to secure the military. Examples such as the Car Nicobar Air Base, wrecked by the 2004 Indian Ocean Tsunami or that of the Eastern Naval Command at Vishakhapatnam, damaged by Cyclone Hudhud in 2014 are noteworthy (India Today 2014). While rebuilding the air base, since the coastlines were erased by the tsunami, the Air Force moved into the island's interior so that the base remained safe even if another similar disaster strikes in the future (Press Information Bureau, 2014c). Not just disasters, but also other effects such as glacial recession and temperature rise are also being assessed. For instance, temperature-controlled equipment including tanks, submarines and aircrafts-which are also known for their high consumption of halons (with high Global Warming Potential)—will have to be adapted to rising temperatures - to sustain their operational capabilities.

Since the military is deployed in some of the most ecologically fragile and politically volatile areas, the stakes for it are much higher. Climate change could also physically alter the battlefield, forcing the armed forces to change the game plan and adopt fresh strategies. For example, climate change is reportedly responsible for accelerated glacial retreat in the Hindu Kush Himalaya region, according to many scientific studies (Wester et al. 2019). The Siachen glacier, world's highest battleground where Indian and Pakistani soldiers are stationed on both sides of the contested border, is said to be melting at a fast pace, due to climate change and overwhelming presence of troops in the region that is putting pressure on the area's ecosystems. The number of ice avalanches has increased, leading to several deaths (of soldiers), prompting the army to 'rethink deployment procedures' and closely monitor the rate of climate change with the help of scientific research institutes (Peri 2016). As summed up by General Bikram Singh (2018), former Chief of the Army Staff:

\footnotetext{
${ }^{6}$ Information regarding Defence Institute of High Altitude Research and its activities can be found here: https://www.drdo.gov.in/drdo/labs1/DIHAR/English/indexnew.jsp?pg=achieve.jsp.
} 
'In the Indian context, melting of glaciers, flash floods, encroaching seas, cyclones, rising temperatures in the deserts and plains, forest fires and higher water levels in the riverine terrain will necessitate a conscious re-examination of the ways we fulfil our constitutional obligations. Our military's peacetime locations, operational deployments, equipment profile, organizational structures, logistic sustenance, tactics, operational art and war fighting strategies will have to be revisited. Internal security management architecture, too, would require sprucing up. Since transformation in large organizations is a time consuming process, we need to act fast to think through the challenge with collective wisdom and draw up necessary road maps.'

\section{Counter-currents to climatization of India's military strategy}

On the one hand, the influence of norms of integrating climate risks into military strategy, which are increasingly becoming transnational, in the Indian military cannot be understated. This is manifested through, among other signs, the presence of Indian retired and military officials in epistemic networks such as GMACCC $^{7}$ and the adoption of lexicon of climate security by military scholars/officials and within the military documents. This can be partly attributed to the nature of the climate problem itself, which is seen as a transnational issue that requires transnational and trans-sectoral solutions, bringing different stakeholders, including the military, into the fold of solution-finding exercise. On the other hand, the Indian military's engagement with environmental issues in general, particularly conservation and protection, is not new. Yet, these norms have not been institutionalized, except in cases such as HADR and the ETF (through policy interventions) to some extent.

In fact, there is general acceptance among the epistemic communities dealing with climate change and/or security that the military's role in environmental and climate change issues should be on an 'as-needed basis' (and even no role at all), rather than an institutional one. Some believe that there should be institutionalized policies to govern the involvement of the military in issues such as disaster management. Others contend that the NDRF should instead be empowered to carry out the task it was created for in the first place, without any obstacles (based on several interviews with military personnel, academics and bureaucrats conducted by the author).

The question of whether the 'sphere of military action' should be allowed to 'infiltrate the "grey areas" of everyday life' (Cooper 2006) has been pivotal in deciding the role of the military in climate change-related issues, particularly in India. While some believe that the military is a respectable entity that is known to work with discipline and time-bound procedures that could also contribute to environmental and climate objectives, others deem the military not to be geared to deal with larger complexities of environmental and climate change. For instance, according to a former official of the Ministry of Environment and Forests (now Ministry of Environment, Forest and Climate Change), Ministry of Environment and Forests, the military could

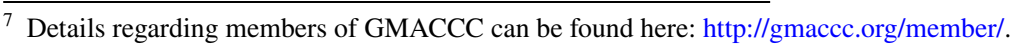


and should only handle simple tasks such as planting trees or tackling the phase-out of ODS (2014, personal communication). Inherent to these arguments are facets of civil-military relations, bureaucratic politics and trade-offs between environmental/ climate objectives and security interests. For example, the retarded pace of defence reforms in the country is blamed upon 'bureaucratic politics' and 'political apathy' (Mukherjee 2009), as well as 'strong administrative, procedural and bureaucratic controls' over the military (Shukla 2012). Defence reforms are also linked to the military's ability to adapt to newer challenges such as climate change and these require budgetary allocation, which according to many ex-military officials is grossly insufficient (personal communication with military officials and security experts).

Similarly, the lack of coordination between civilian and military agencies, owing to turf war and parochialism (an 'institutional disease' as termed by many ex-military officials) that pervades the bureaucracy, is also cited as a reason for delay for action or non-action on critical issues, including climate change (personal communication with former military officials). It must be noted here that the military, despite being prepared for contingency planning, is known to be a rigid organization with its own standard operating procedures (SOPs), terms of reference (ToRs) and so on. According to a serving military official (anonymous), since the armed forces are trained to fight wars, they would be reluctant to train for other activities such as HADR. Moreover, in India's case, when the country faces rather tangible territorial threats from Pakistan and China, it cannot afford to divert resources into climate change-related issues. It is projected as an either-or situation. P. G. Kamath, a retired army officer, states, 'Environmental and climate security cannot be achieved at the cost of territorial security (2017, personal communication).'

\section{Conclusion}

In conclusion, this paper highlights the different approaches adopted by security actors to incorporate climate change concerns within their strategy and planning through the framework of climatization by using the case study of the Indian military. It provides an analysis of the military security-climate change interface, by going beyond the traditional notions of climate security based on the securitization theory. Indeed, the pathways being followed by the Indian military adhere more to the process of climatization even though they utilize the grammar of securitization and riskification occasionally. In comparison with the militaries of the USA, UK, Sweden, France and some of the other Western countries, the Indian military is far behind in: first, recognizing climate change as critical to their operations, strategy and survival; and second, integrating climate change with the full scope of its strategy. In fact, no military in the world has perhaps succeeded in accomplishing the second goal.

In the Indian context, neither the civilian establishment nor the military is entirely open to the idea of addressing climate change from a security perspective in a practical sense. Instead, the climate logic is being espoused in order to tackle the implications of climate change for India's security and, more specifically, military security. The measures that are being planned and implemented by the military, in 
conjunction with the civilian authorities, are leading to subtle shifts in goalposts and reformation of procedures to accommodate climate change within the military strategy through a logic that complements and/or supplements military preparedness and effectiveness, but does not result in militarization of climate change. Exceptions are, however, made in cases such as the direct impacts of climate change on the military at tactical, operational and strategic levels.

The Indian military deals with many other environmental issues within the gamut of issues of concern, without restricting the discourse to just climate change, thereby resembling environmentalization practices. Importantly, the discourse on environment and development (positions adopted by the civilian agencies) has also had an influence on the military's engagement with security implications of climate change. However, there are increasing signs of incremental measures being taken in this direction as seen in the cases of expansion of renewable energy and studying/monitoring the impacts of climate change on it at various levels. This, as already specified, can be associated with 'symbolic', 'precautionary', 'strategic' and 'transformative' climatizing moves, more so 'symbolic' and 'precautionary'. These typologies may not be readily applicable in all contexts, especially where civil-military relations are complicated by predilections for military dictatorship, prevalence of weak/disempowered civilian governance machineries or other socio-cultural and political dynamics.

Futuristically, the Indian military is inclined to work towards climate change mitigation and adaptation, driven by both necessity and demand for stewardship by joining the country's efforts to address climate change at the national level. In HADR, it has spread its wings outside the national territory to cooperate with other countries (particularly since the 2004 Indian Ocean Tsunami). With the growing references to climate-induced extreme weather events serving as a catalyst for greater involvement of the Indian armed forces in such exercises in the region (and perhaps beyond), this element is expected to act as a strong stimulus for climatization.

By bringing out varied interpretations of climate security-military interface through securitization, riskification and climatization in different contexts, the paper attempts to analyse why and how militaries address climate change. There is further scope for comparative research on the militaries of the North and South, which could provide a more holistic view of the contextual conditions that influence climatization as well as, from a policy point of view, avoid universalization of these norms that are being promoted by the international organizations and networks. To some extent, such studies can also facilitate a more holistic understanding and even redefinition of climate security at both conceptual and practical levels.

Acknowledgements Open access funding provided by Manipal Academy of Higher Education, Manipal. The paper is carved out of the author's $\mathrm{PhD}$ thesis, titled 'Military Dimensions of Environmental Security: An Indian Perspective' (awarded in 2018), supervised by Nanda Kishor M. S., Associate Professor, Department of Geopolitics and International Relations, Manipal Academy of Higher Education (deemedto-be University) (MAHE). The PhD study was facilitated by MAHE's Dr TMA Pai Scholarship. The paper was further strengthened during the author's postdoctoral stint at the Faculty of Social and Political Sciences, University of Lausanne, under the Swiss Government Excellence Scholarship (2018-19). The author would like to thank Lucile Maertens (Lecturer, Faculty of Social and Political Sciences, University of Lausanne, Switzerland), Stefan Aykut, (Junior Professor, Fakultät WISO, Universität Hamburg, Germany) and Adrien Estève (PhD student, Center for International Studies and Research, Sciences Po, France) for their valuable comments on the initial drafts of this paper. The author would also like to 
express sincere gratitude to the reviewers for providing precise and detailed inputs to refine the paper further.

\section{Compliance with ethical standards}

Conflict of interest The author states that there is no conflict of interest.

Open Access This article is licensed under a Creative Commons Attribution 4.0 International License, which permits use, sharing, adaptation, distribution and reproduction in any medium or format, as long as you give appropriate credit to the original author(s) and the source, provide a link to the Creative Commons licence, and indicate if changes were made. The images or other third party material in this article are included in the article's Creative Commons licence, unless indicated otherwise in a credit line to the material. If material is not included in the article's Creative Commons licence and your intended use is not permitted by statutory regulation or exceeds the permitted use, you will need to obtain permission directly from the copyright holder. To view a copy of this licence, visit http://creativecommons.org/licen ses/by/4.0/.

\section{References}

Ali, S.H.C., and R.J. Pincus. 2018. The Role of the Military in Environmental Peacebuilding. In Routledge Handbook of Environmental Conflict and Peacebuilding, ed. A. Swain and J. Öjendal, 306314. Abingdon: Routledge.

Aykut, S.C., J. Foyer, and E. Morena. 2017. Globalising the Climate. COP21 and the Climatisation of Global Debates. Edited Volume. London and New York: Routledge.

Balzacq, T., T. Basaran, D. Bigo, E.P. Guittet, and C. Olsson. 2010. Security practices. In: R. A. Denemark (ed.) International Studies Encyclopaedia Online. London: Blackwell Publishing. Blackwell Reference Online. 18 March, http://www.isacompendium.com/subscriber/tocnode?id=g978144433 6597_chunk_g978144433659718_ss1-2. Accessed 29 Sept 2019.

Barnett, J. 2001. The Meaning of Environmental Security: Ecological Politics and Policy in the New Security Era. London: Zed Books.

Barthwal-Datta, M. 2012. Understanding Security Practices in South Asia: Securitization Theory and the Role of Non-State Actors. London and New York: Routledge.

Bilgin, P. 2010. The 'Western-centrism' of security studies: 'Blind spot' or constitutive practice? Security Dialogue 41(6): 615-622.

Boas, I. 2014. Where is the South in Security Discourse on Climate Change? An Analysis of India. Critical Studies on Security 2(2): 148-161.

Briggs, C.M. 2012. Climate Security, Risk Assessment and Military Planning. International Affairs 88(5): 1049-1064.

Butts, K.H. 1999. The Case for DoD Involvement in Environmental Security. In Contested Grounds: Security and Conflict in the New Environmental Politics, ed. D.H. Deudney and R.A. Matthew, 109126. Albany: State University of New York Press.

Buzan, B., O. Wæver, and J. de Wilde. 1998. Security: A New Framework for Analysis. London: Lynne Rienner Publishers.

Campbell, K., J. Gulledge, J.R. McNeill, J. Podesta, P. Ogden, L. Fuerth, R.J. Woolsey, A.T.J. Lennon, J. Smith, R. Weitz, and D. Mix. 2007. The Age of Consequences: The Foreign Policy and National Security Implications of Global Climate Change. Washington, DC: Center for Strategic and International Studies and Center for American Security.

Capie, D. 2015. The United States and Humanitarian Assistance and Disaster Relief (HADR) in East Asia: Connecting Coercive and Non-Coercive Uses of Military Power. Journal of Strategic Studies 38(3): 309-331.

Center for Naval Analyses. 2007. National Security and the Threat of Climate Change. CNA's Military Advisory Board Report, https://www.cna.org/CNA_files/pdf/National\%20Security\%20and\%20the \%20Threat\%20of\%20Climate\%20Change.pdf. Accessed 29 Sept 2019. 
Chaturvedi, S., and D. Timothy. 2015. Climate Terror: A Critical Geopolitics of Climate Change. London: Palgrave Macmillan.

Chowdhury, A. 2009. The Coming Crisis: From Bangladesh to India....and then the Rest? Himal South Asian, 1 October, https://www.himalmag.com/the-coming-crisis/. Accessed 10 March 2020.

Conca, K., and J. Wallace. 2009. Environment and Peacebuilding in War-torn Societies: Lessons from the UN Environment Programme's Experience with Postconflict Assessment. Global Governance 15(4): 485-504.

Cooper, M. 2006. Pre-empting Emergence: The Biological Turn in the War on Terror. Theory, Culture and Society 23(4): 113-135.

Corry, O. 2012. Securitisation and 'Riskification': Second-Order Security and the Politics of Climate Change. Millennium-Journal of International Studies 40(2): 235-258.

Dabelko, G.D. 2009. Planning for Climate Change: The Security Community's Precautionary Principle. Climatic Change 96(13): 13-21.

Dalby, S. 1992. Ecopolitical Discourse: 'Environmental Security' and Political Geography'. Progress in Human Geography 16(4): 503-522.

Dasgupta, C. 2016. Climate Change and India's Security Environment. In India's National Security: Annual Review 2015-16, ed. Satish Kumar, 389-398. New Delhi: Routledge.

Deudney, D. 1991. Environment and Security: Muddled Thinking. Bulletin of the Atomic Scientists 47(3): $22-28$.

Dyer, H. 2001. Environmental Security and International Relations: The Case for Enclosure. Review of International Studies 27(3): 441-450.

Floyd, R. 2008. The environmental security debate and its significance for climate change. The International Spectator 43(3): 51-65.

Floyd, R. 2010. Security and the Environment: Securitisation Theory and US Environmental Security Policy. Cambridge: Cambridge University Press.

Floyd, R. 2011. Can Securitization Theory be Used in Normative Analysis? Towards a Just Securitization Theory. Security Dialogue 42(4-5): 427-439.

Gilbert, E. 2012. The militarisation of climate change. ACME: An International E-Journal for Critical Geographies $11(1): 1-14$.

Harris, P. 2015. Militarism in Environmental Disguise: The Greenwashing of an Overseas Military Base. International Political Sociology 9(1): 19-36.

Hartman, J., K. Butts, B. Bankus, and S. Carney. 2012. Sustainability and National Security. Carlisle: Center for Strategic Leadership, United States Army War College.

Staff, Headquarters Integrated Defence. 2017. Joint Doctrine Indian Armed Forces. New Delhi: Ministry of Defence.

Homer-Dixon, T.F. 1994. Environmental Scarcities and Violent Conflict: Evidence from Cases. International Security 19(1): 5-40.

Homer-Dixon, T.F. 2007. Terror in the Weather Forecast. The New York Times, 24 April, https://www.nytim es.com/2007/04/24/opinion/24homer-dixon.html. Accessed 25 Sept 2019.

India Today. 2014. Cyclone Hudhud Impact: Navy Suffered Rs 2,000 Crore Loss in Vizag. 14 October 2014, https://www.indiatoday.in/india/story/cyclone-hudhud-vizag-navy-rs-2000-crore-loss-chandrabab u-naidu-andhra-223084-2014-10-14. Accessed 29 Sept 2019.

Indian Navy. Role of Navy. https://www.indiannavy.nic.in/content/role-navy Accessed 29 Sept 2019.

International Military Council on Climate and Security. (forthcoming) The World Climate and Security Report 2020. https://imccs.org/publications/. Accessed 29 Sept 2019.

Kumar, M. 2012. Resource Optimisation Through Environmental Leadership. New Delhi: Centre for Air Power Studies and Knowledge World.

Maertens, L. 2019. From Blue to Green? Environmentalization and Securitization in UN Peacekeeping Practices. International Peacekeeping 26(3): 302-326.

McDonald, M. 2012. Security, the Environment and Emancipation: Contestation over Environmental Change. London and New York: Routledge.

Mittal, S. 2015. Indian Defense Forces Set to Auction 300 MW Solar Power Capacity. Clean Technica, 13 January, https://cleantechnica.com/2015/01/13/indian-defense-forces-set-auction-300-mw-solar-power -capacity/. Accessed 29 Sept 2019.

Mukherjee, A. 2009. Relearning Lost Lessons: The Indian Army in Counterinsurgency. In The Routledge Handbook of Asian Security Studies, ed. S. Ganguly, A. Scobell, and J. Liow, 139-157. London and New York: Routledge. 
Mukherjee, A. et al. 2012. Net Security Provider: India's Out-of-Area Contingency Operations. New Delhi: Manohar Parrikar Institute for Defence Studies and Analyses \& Magnum Books Pvt Ltd.

National Disaster Management Authority. 2009. National Policy on Disaster Management 2009. Ministry of Home Affairs, Government of India, http://www.ndma.gov.in/images/guidelines/national-dm-polic y2009.pdf. Accessed 29 Sept 2019.

North Atlantic Treaty Organisation. 2014. Green Defence Framework. http://www.natolibguides.info/ 1d.php?content_id=25285072. Accessed 29 September 2019.

Oels, A. 2012. From 'Securitization' of Climate Change to 'Climatization' of the Security Field: Comparing Three Theoretical Perspectives. In Climate Change, Human Security and Violent Conflict, ed. J. Scheffran, M. Brzoska, H.G. Brauch, P.M. Link, and J. Schilling. Berlin: Springer.

Pai, N. 2017. Climate Change and National Security. In Proceedings of Centre for Law Warfare Studies Conference; January, New Delhi. https://takshashila.org.in/wp-content/uploads/2017/02/ClimateChangeNationalSecurity.pdf. Accessed 29 Sept 2019.

Parsons, R.J. 2011. Strengthening Sovereignty: Security and Sustainability in an Era of Climate Change. Sustainability 3: 1416-1451.

Peri, Dinakar. 2016. Climate change forces Army to rethink Siachen deployment procedures. The Hindu. 20 July, https://www.thehindu.com/news/national/Climate-change-forces-Army-to-rethink-Siachen-deplo yment-procedures/article14499225.ece. Accessed 29 Sept 2019.

Press Information Bureau. 2014a. 'Swachh Bharat Campaign' and Green Initiatives Launched by Indian Navy. Government of India, 2 October, http://pib.nic.in/newsite/PrintRelease.aspx?relid=110257. Accessed 29 Sept 2019.

Press Information Bureau. 2014b. Green Footprint of a Blue Water Navy. Government of India, 4 June, http:// pib.nic.in/newsite/PrintRelease.aspx?relid=105422. Accessed 29 Sept 2019.

Press Information Bureau. 2014c. Book Release by Chief of Air Staff on Tenth Anniversary of Tsunami. Government of India, 26 December, http://pib.nic.in/newsite/PrintRelease.aspx?relid=114126. Accessed 29 Sept 2019.

Press Information Bureau. 2016. Indian Navy Pledges 1.5 Per Cent of its Works Budget towards Renewable Energy Generation: World Environment Day-2016. Government of India, 5 June. http://pib.nic. in/newsite/PrintRelease.aspx?relid=145978. Accessed 29 Sept 2019.

Pubby, M. 2016. International Fleet Review 2016: Navy to Showcase Warship Running on Biofuel at Vizag. The Economic Times, 5 February, http://www.indiandefensenews.in/2016/02/ifr-2016-navy-to-showc ase-warship.html. Accessed 29 Sept 2019.

Ramesh, J. 2015. Green Signals: Ecology, Growth, and Democracy in India. New Delhi: Oxford University Press.

Ranjan, A. 2016. Migration from Bangladesh: Impulses, Risks and Exploitations. The Round Table: The Commonwealth Journal of International Affairs 105(3): 311-319.

Sahu, A.K. 2017. The Securitisation of the Climate Change Issue: A Multisectoral Approach to Security. World Affairs 21(4): 26-37.

Schwartz, P., and D. Randall. 2003. An Abrupt Climate Change Scenario and Its Implications for United States National Security. Emeryville, CA: Global Business Network.

Shukla, R. 2012. Civil Military Relations in India. New Delhi: Centre for Law Warfare Studies. Manekshaw Paper 36. https://www.claws.in/static/MP36_Civil-Military-Relations-in-India.pdf. Accessed 25 Sept 2019.

Singh, A. 2015. Climate Change and Maritime Security in the Indian Ocean Region. Journal of Defence Studies 9(1): 63-82.

Singh, B. 2018. How climate change can affect national security. The Hindustan Times, 5 November, https:// www.hindustantimes.com/analysis/how-climate-change-can-affect-national-security/story-JKZ1iv60ox DcDEex1LFIwN.html. Accessed 29 Sept 2019.

Smith, D., and J. Vivekananda. 2007. A Climate of Conflict: The Links Between Climate Change, Peace and War. London: International Alert.

Territorial Army. Ecological TA. https://www.territorialarmy.in/ecological.aspx. Accessed 29 Sept 2019.

Trombetta, M.J. 2008. Environmental Security and Climate Change: Analysing the Discourse. Cambridge Review of International Affairs 21(4): 585-602.

Trombetta, M.J. 2011. Rethinking the Securitization of the Environment: Old Beliefs, New Insights. In Securitization Theory: How Security Problems Emerge and Dissolve, ed. T. Balzacq, 135-149. Abingdon: Routledge. 
United Nations. 2019. Massive Displacement, Greater Competition for Scarce Resources Cited as Major Risks in Security Council Debate on Climate-Related Threats. UN Press Release, 25 January. https:// www.un.org/press/en/2019/sc13677.doc.htm Accessed 29 Sept 2019.

Von Lucke, F., Z. Wellmann, and T. Diez. 2014. What's at Stake in Securitising Climate Change? Towards a Differentiated Approach. Geopolitics 19(4): 857-884.

Werrell, C.E., F. Femia, S. Goodman, and S. Fetzek. 2017. A Responsibility to Prepare: Governing in an Age of Unprecedented Risk and Unprecedented Foresight. Washington, DC: The Center for Climate and Security. CCS Briefer no. 38.

Wester, P., A. Mishra, A. Mukherji, and A.B. Shrestha. 2019. The Hindu Kush Himalaya Assessment: Mountains, Climate Change, Sustainability and People. Kathmandu and Cham: International Centre for Integrated Mountain Development and Springer. Edited Volume.

Wilkinson, C. 2007. The Copenhagen School on Tour in Kyrgyzstan: Is Securitization Theory Useable Outside Europe? Security Dialogue 38(1): 5-25.

Publisher's Note Springer Nature remains neutral with regard to jurisdictional claims in published maps and institutional affiliations. 